\title{
The Regulation of Some Enzymes Involved in Ammonia Assimilation by Rhizobium japonicum
}

\author{
By P. F. FOTTRELL AND PHYLLIS MOONEY \\ Department of Biochemistry, University College, Galway, Irish Republic
}

(Accepted for publication 25 August 1969)

\begin{abstract}
SUMMARY
The concentrations of three enzymes active in ammonia assimilation by Rhizobium japonicum (glutamate dehydrogenase, aspartate aminotransferase, alanine aminotransferase) were influenced considerably by the $\mathrm{N}$-source in the culture medium. Relatively high concentrations of these enzymes were present when $R$. japonicum was grown in a medium containing $\mathrm{NH}_{4} \mathrm{Cl}+$ 2-oxoglutarate. Relatively low amounts of these enzymes were found in bacteria grown in the presence of various amino acids. Active protein and RNA synthesis were necessary for the induction of the enzymes by $\mathrm{NH}_{4} \mathrm{Cl}+$ 2-oxoglutarate.
\end{abstract}

\section{INTRODUCTION}

It has been known for some time that ammonia formed during symbiotic nitrogen fixation is rapidly incorporated into amino acids (e.g. glutamate, aspartate, alanine; Aprison, Magee \& Burris, 1954), but relatively little is known about the enzymes which catalyse these reactions in soybean nodules. We showed (Fottrell \& Montgomery, I968) that several enzymes active in ammonia assimilation, including glutamate dehydrogenase, aspartate aminotransferase and alanine aminotransferase were present in the bacteroids of soybean nodules. In the present report the mechanism involved in the regulation of these enzymes was investigated in Rhizobium japonicum (symbiont of soybeans).

\section{METHODS}

Rhizobium japonicum strain 392 (obtained from C. L. Masterson, Agricultural Institute, Wexford, Irish Republic), which is a slow-growing strain, was grown in a defined medium (Evans \& Lowe, 1964) with different $\mathrm{N}$-sources as indicated in Table $\mathrm{I}$. Cultures were grown in 4-1. Erlenmeyer flasks, from an inoculum of standard size, on an orbital shaker at $28^{\circ}$. Growth was estimated by measuring the extinction at $562 \mathrm{~m} \mu$.

At a suitable stage of growth, bacteria were harvested by centrifugation, washed with $0.9 \%(\mathrm{w} / \mathrm{v}) \mathrm{NaCl}$ and suspended (I g. bacteria/1. $5 \mathrm{ml}$. buffer) in $0.06 \mathrm{M}$-phosphate buffer $(\mathrm{pH} \mathrm{7 \cdot 2)}$ containing I mM-glutathione (reduced) $+0 \cdot 1 \%(\mathrm{w} / \mathrm{v})$ Triton X-Ioo. The bacteria were disrupted with an MSE $60 \mathrm{~W}$ ultrasonic disintegrator for $\mathrm{r} \cdot 5 \mathrm{~min}$. at less than $5^{\circ}$, then centrifuged at $34,000 \mathrm{~g}$ for $90 \mathrm{~min}$. and the clear supernatant fluid used for the enzyme assays. Enzymes were assayed spectrophotometrically at $340 \mathrm{~m} \mu$ as described by Bergmeyer (1965). Assays were also made for glutamine synthetase and carbamyl phosphate synthetase by the methods of Woolfolk, Shapiro \& Stadtman (1966) and Metzenberg et al. (1957), respectively. Specific enzyme activity 
was expressed in International Units/g. protein (Bergmeyer, 1965). Protein was assayed by a modified biuret reaction (Gornall, Bardawill \& David, 1949).

Net synthesis of glutamate and aspartate was shown by using ${ }^{14} \mathrm{C}-2$-oxoglutarate $(3.2 \mu \mathrm{c} / \mu \mathrm{M})$ (Radiochemical Centre, Amersham, Buckinghamshire, England) as described by Weiss (1967). Glutamate and aspartate were separated by thin-layer chromatography on cellulose with isopropanol + formic acid + water $(40+2+10$, by vol.) for $3 \mathrm{hr}$. Autoradiographs were prepared with Kodak Industrex X-ray Film.

Table I. The effect of various nitrogen sources in the medium on enzymes in Rhizobium japonicum

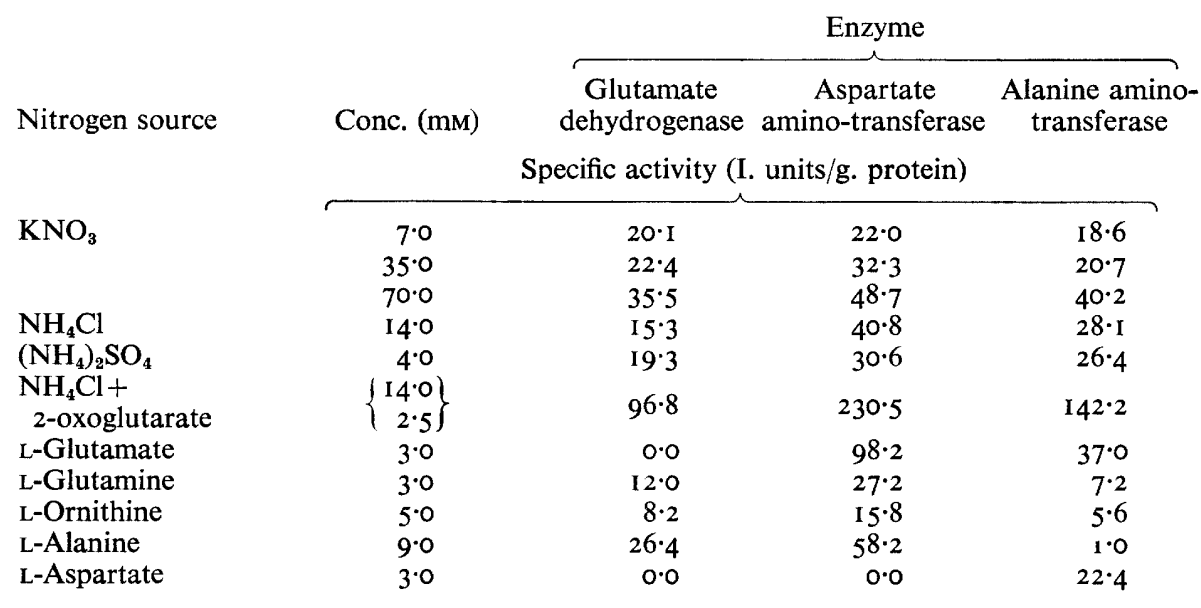

\section{RESULTS}

The amounts of glutamate dehydrogenase, aspartate aminotransferase and alanine aminotransferase were influenced by the N-source (Table I). One of the most interesting findings was the relatively high amounts of enzyme in bacteria grown with $\mathrm{NH}_{4} \mathrm{Cl}+2$-oxoglutarate. In contrast, glutamate dehydrogenase was not detected in bacteria grown with glutamate or aspartate. Aspartate aminotransferase was absent when the medium contained aspartate and alanine aminotransferase activity was not detected in bacteria grown with alanine. Further measurements showed that glutamine synthetase activity was very low in bacteria grown with $\mathrm{KNO}_{3}(7 \mathrm{mM})$ or $\mathrm{NH}_{4} \mathrm{Cl}$ $(0.014 \mathrm{M})$, but was increased over I00-fold in bacteria grown with glutamate ( $3 \mathrm{~mm})$. Carbamyl phosphate synthetase activity, in contrast, was relatively high in bacteria grown with nitrate, but was absent from bacteria grown with ornithine $(5 \mathrm{~mm})$ or alanine $(9 \mathrm{~mm})$.

To determine the mechanism involved in the regulation of glutamate dehydrogenase and aspartate aminotransferase, bacteria were grown in a medium containing aspartate $(3 \mathrm{~mm})$ for $48 \mathrm{hr}$. The bacteria were harvested under sterile conditions, washed with sterile $0.9 \%(\mathrm{w} / \mathrm{v}) \mathrm{NaCl}$ and inoculated into new medium containing 2-oxoglutarate $(2.5 \mathrm{mM})+\mathrm{NH}_{4} \mathrm{Cl}(0.014 \mathrm{M})$, in place of aspartate. Various concentrations of actinomycin $\mathrm{D}$, puromycin or cycloheximide were added to replicate cultures in the new medium; control cultures contained no antibiotic. The results (Table 2) showed that enzyme induction was inhibited when either antibiotic was included in the medium. 
With the exception of actinomycin D, which inhibited growth by $22 \%$ at I $\mu \mathrm{g} . / \mathrm{ml}$. medium, there was no inhibition of growth by puromycin, cycloheximide or actinomycin $\mathrm{D}$ at the concentrations given in Table 2. Alanine amino-transferase activity was investigated only with actinomycin $\mathrm{D}$; the results were very like those obtained for the other two enzymes. On the basis of these results we concluded that active protein and RNA synthesis were necessary for the induction of all three enzymes in Rhizobium japonicum.

Table 2. Effects of inhibitors of RNA and protein synthesis on enzyme induction in Rhizobium japonicum

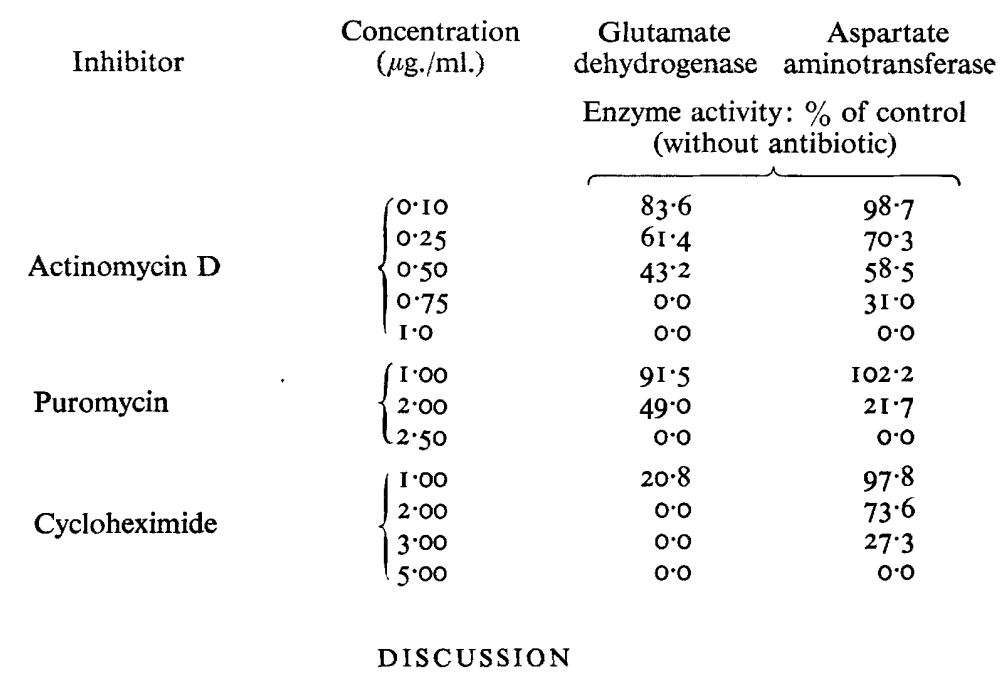

The results show that enzymes probably active in the assimilation of ammonia in soybean nodules, were influenced to a considerable degree in Rhizobium japonicum by the $\mathrm{N}$-source in the growth medium. As regards assimilation of fixed nitrogen by legume nodules it was interesting that glutamate dehydrogenase, aspartate aminotransferase and alanine aminotransferase were induced in cultures of $R$. japonicum by $\mathrm{NH}_{4} \mathrm{Cl}+2$-oxoglutarate. Ammonia is the first stable intermediate formed in soybean bacteroids during nitrogen fixation (Bergersen, 1965) and 2-oxoglutarate would probably be supplied by the host legume since very little isocitrate dehydrogenase activity was detected in the bacteroids in our experiments. It seems that in bacteroids of soybean nodules, glutamate, aspartate and alanine are important intermediates in the assimilation of fixed nitrogen.

This work was supported by a research grant from An Foras Taluntais (The Agricultural Institute). One of us (P.M.) thanks the Department of Education (Dublin) for a research scholarship. We are grateful to Dr H. J. Robinson (Merck \& Co. Inc., New Jersey, U.S.A.) for a gift of actinomycin D. 


\section{REFERENCES}

Aprison, M. H., MAGEE, W. E. \& Burris, R. H. (I954). Nitrogen fixation by excised soybean nodules. J. biol. Chem. 208, 29.

BERGERSEN, F. J. (1965). Ammonia-an early stable product of nitrogen fixation by soybean root nodules. Aust. J. biol. Sci. r8, I.

BergmeYer, H. U. (1965). In Methods of Enzymatic Analysis. Ed. by H. U. Bergmeyer. London: Academic Press.

Evans, H. J. \& Lowe, R. H. (1964). Preparation and some properties of a soluble nitrate reductase from Rhizobium japonicum. Biochim. biophys. Acta 85, 377.

Fottrell, P. F. \& Montgomery, P. (1968). Enzymes involved in the assimilation of ammonia in bacteroids of soybean nodules and in Rhizobium japonicum. Abstr.5th Meet. Fed. Europ. Biochem. Soc., Prague, p. 57.

Gornall, A. G., Bardawill, C. J. \& David, M. M. (I949). Determination of serum proteins by means of the biuret reaction. J. biol. Chem. $\mathbf{1 7 7}, 75 \mathrm{I}$.

Metzenberg, R. L., Hall, L. M., Marshall, M. \& Cohen, P. P. (1957). Studies on the biosynthesis of carbamyl phosphate. J. biol. Chem. 229, 1019.

WEISs, E. (1967). Transaminase activity and other enzymatic reactions involving pyruvate and glutamate in Chlamydia. J. Bact. 93, 177.

Woolfolk, C. A., Shapiro, B. \& Stadtman, E. R. (1966). Regulation of glutamine synthetase. Arch. Biochem. Biophys. 116, 177. 